\title{
Interaction of Central Bank Independence and Transparency: Bibliometric Analysis
}

http://doi.org/10.21272/bel.4(2).109-115.2020

\section{Dudchenko Victoria Yuriivna, ORCID: https://orcid.org/0000-0002-0054-8362}

$\mathrm{PhD}$, Associate Professor, Department of International Economic Relationships, Sumy State University, Sumy, Ukraine

\begin{abstract}
This paper summarizes the arguments and counterarguments within the scientific discussion on the central bank independence and central bank transparency interaction. he main purpose of the research is to define the substantial relationships between central banks' independence and transparency based on scientific research results. Systematization literary sources and approaches for the definition of central banks independence and transparency indicate that there is no generalized approach to the hierarchy of these concepts. Existing empirical studies have shown that the independence and transparency of the central bank can be interconnected components to increase the effectiveness and flexibility to solve tasks regarding the provision of currency stability and financial stability in general. Methodological tools of the research methods are Google Trends and VOSviewer instruments. The presented results of an empirical analysis of trends regarding the dynamics of the search query number by the keywords "central bank independence" and "central bank transparency" show a decrease from 2004 to the present, with a significant predominance of central bank independence over transparency throughout the study period. The results of bibliometric analysis of keyword coincidence while writing scientific articles show that researchers of the central bank independence very rarely link its solution with the transparency aspects study, while researchers of central bank transparency often study this problem in direct connection with their independence analysis. Along with this, the issues of transparency of central banks are often studied simultaneously with the analysis of their independence. The research empirically confirms and theoretically proves that the central bank's independence is the primary category that creates the conditions for the study of its transparency. The study results provide a scientific ground to study the strength and direction of the relationship between the levels of transparency and independence of the central bank, identifying quantitative indicators to describe these relationships and can be useful for further research to ensure the central bank efficiency.
\end{abstract}

Keywords: Bibliometric Analysis, Central Bank, Coincidence, Google Trends, Independence, Interaction, Transparency, VoSviewer.

JEL Classification: E58, F65, G20, P34.

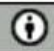

This work is licensed under a Creative Commons Attribution 4.0 International License

Cite as: Dudchenko, V.Yu. (2020). Interaction of Central Bank Independence and Transparency: Bibliometric Analysis. Business Ethics and Leadership, 4(2), 109-115. http://doi.org/10.21272/bel.4(2).109-115.2020.

(C) The Author, 2020. This article is published with open access at Sumy State University.

\section{Introduction}

Trends in democratization and informatization of society necessitate the growth of publicity of processes in all spheres of the state governance. Given the significant level of interconnectedness of economic processes in all fields of the national economy and the decisive role of the banking system in ensuring economic development, disclosure of economic information on banking regulation is a prerequisite for improving the financial planning of real sector entities, financial institutions and households long-term financial stability and a prerequisite for progressive economic development. Besides, increasing the level of publicity and transparency minimizes the possibility of political influence on the decisions of the central bank, which allows it to maintain the appropriate level of its de facto independence and form a positive perception in society. Thus, an essential area in the study of the effectiveness of banking regulation is to determine the role of independence and transparency of the central bank. Thus, the study of the essential and substantive relationships between the categories of "central bank independence" and "central bank transparency" becomes relevant. It enables to form a basis to substantiate the causal relationships between them. 


\section{Literature Review}

Central bank development trends show a close relationship between their independence and transparency. Thus, some authors consider transparency as a component of central bank independence. Therefore, Fouad et al. (2019) proposed the composition of the elements of the de jure and de facto indices of independence of the central bank, which includes indicators of transparency and accountability. On the other hand, transparency is a condition for increasing the independence of the central bank and relates to an increase in its accountability level, which allows to increase the effectiveness of monetary policy (Dincer and Eichengreen, 2014).

On the other hand, scholar Šmídková (2013) considers three components of ensuring an effective institutional environment for central banks: independence, transparency and accountability. Each of these concepts has its measures, functional purpose and components. At the same time, there are closer links between transparency and accountability, the causal nature of which also remains unclear (Dumiter, 2014).

The need for comprehensive development of independence and transparency of central banks is also evidenced by the main types of these categories, identified by researchers. Thus, the central bank transparency index developed by Eijffinger and Geraats (2006) includes five main components: political transparency (characterizes the level of openness of central bank policy objectives); economic transparency (related to access to economic information used by the central bank for decision-making); procedural transparency (concerning the disclosure of the basic approaches and rules of monetary policy implementation); transparency of monetary policy (characterizes the disclosure of policy decisions, as well as forecast parameters); operational transparency (reflection of the level of results achieved during the implementation of the monetary policy of the central bank).

Along with this, Balls et al. (2018) define the central bank's political and operational independence. Political independence means the absence of opportunities for political influence on the central bank. The authors suppose that operational independence should be considered the autonomy of the central bank in the formation and implementation of monetary policy. Ivanovich (2014) demonstrates a broader approach, distinguishing four types of central bank independence: functional (related to the freedom to choose the goals of monetary policy); institutional (independent choice of monetary policy instruments and specifics of their application); personal (characterizes the peculiarities of the formation of the central bank management); financial (independence of the central bank from the budget and the ban on financing the budget by the central bank). This context indicates the need to identify a set of causal relationships that arise between the independence and transparency of central banks.

Crowe and Meade (2007) argue that the independence and transparency of the central bank are important for effective governance and are complementary concepts. Thus, the growth of central bank independence is associated with lower inflation, while increasing transparency contributes to improving the quality of inflation forecasts. Other scholars analyze the independence and transparency of central banks as separate categories. Thus, independence is associated with the central bank's freedom to choose its own tactics and monetary policy tools. At the same time, transparency characterizes the central bank's willingness to take public responsibility for its decisions (Bernanke, 2010). However, there is a certain specificity regarding the connection of these categories with other aspects of the development of central banks. For example, the independence and transparency of the central bank are determinants of inflation in the country. At the same time, transparency is characterized by a close connection with the level of depth of the country's financial markets and the strength of political institutions, while for the independence of central banks, such a connection is not found.

In terms of determining the relationship between the categories of independence and transparency, one should pay attention to the recommended values for their level. Thus, most studies confirm that the independence of the central bank should reach the highest possible level. On the other hand, it is worth paying attention to the position of the authors who justify the need to determine the optimal level of transparency of the central bank, taking into account the fact that too high its level leads to information overload and may lead to growing uncertainty in the private sector policies that affect their own forecasts. An empirical study in the context of quality assurance of inflation forecasts at different levels of central bank transparency confirmed the authors' hypothesis and justified the need for an optimal level of transparency at which society has sufficient access to general information, while certain specific data that can be interpreted differently, and, accordingly, to determine the growth of uncertainty, should be kept in closed access (van der Cruijsen et al., 2010).

Lustenberger and Rossi (2017) confirm that the central bank's independence and transparency have a similar effect on the quality of macroeconomic and financial forecasts. Besides, empirically, the transparency of the central bank, along with its independence, has a stimulating effect in terms of achieving the central bank 
(Próchniak and Szyszko, 2019). A review of the scientific literature has shown that the transparency and independence of central banks positively affect the quality of central bank management functions and the effectiveness of the monetary policy. Empirical studies have shown that the impact of increasing transparency and independence of central banks can have a positive complementary effect on the achievement of central bank policy targets. At the same time, the relationship between the categories of central bank independence and transparency remains unclear.

\section{Methodology and Results}

At the first stage of the study, we will analyze the scientific interest in the categories of "central bank independence" and "central bank transparency", which has formed in recent years in the world community. We use the Google Trends toolkit, which estimates the number of search queries in the Google system as a whole in the world and by region. The results of this analysis are presented by Fig. 1. The total number of queries in the world during the maximum available period was selected to determine the generalized trends for analysis. From the data of the figure, we can conclude that there is a gradual reduction of scientific interest in the study of these two categories during the research period.

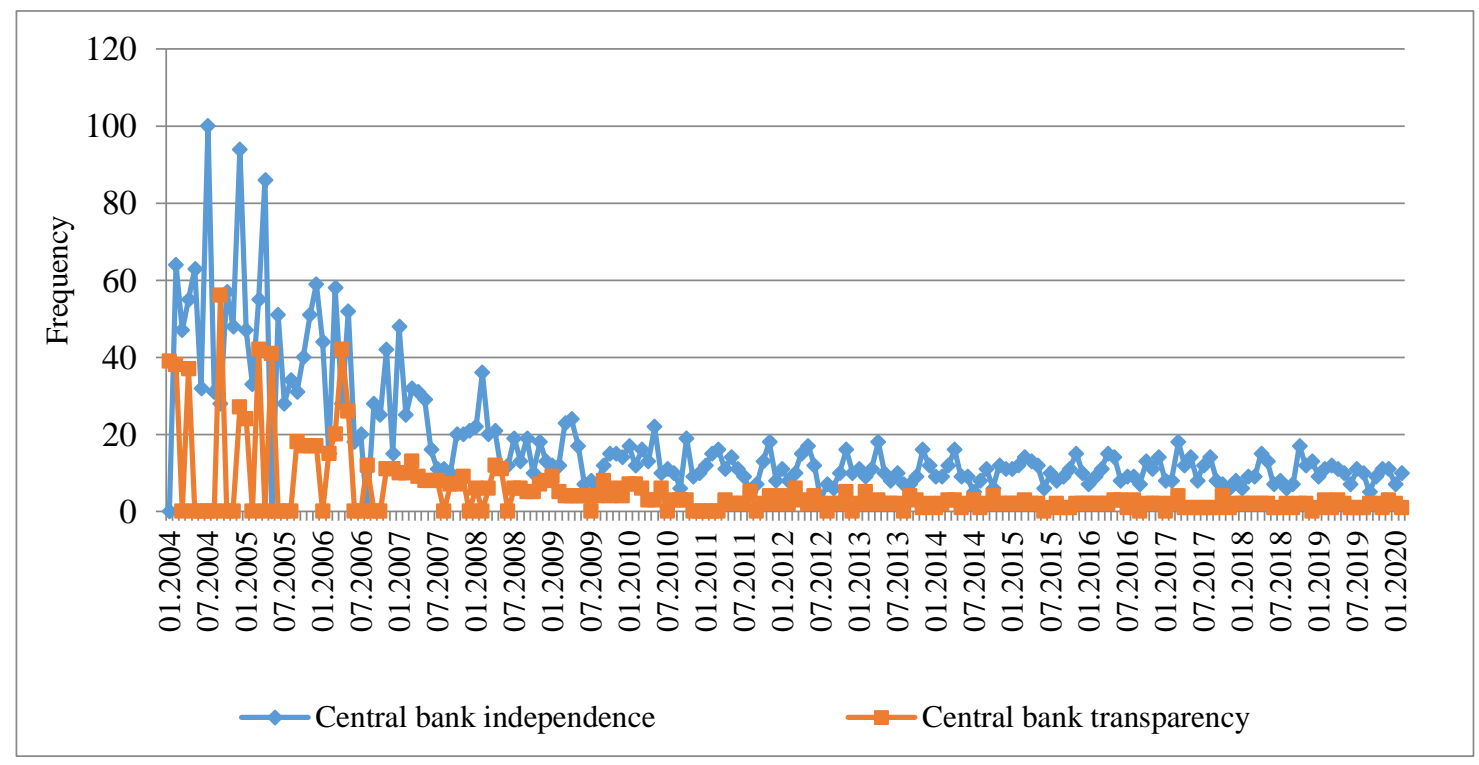

Figure 1. The results of the analysis of the popularity of searches "central bank independence" and "central bank transparency" using Google Trends tools for the period 2004-2020

Source: Own calculations by Google Trends tool

Thus, the most considerable attention of researchers was paid to the search for information during 2004-2006. At this time, the conceptual provisions of the independence and transparency of central banks were intensively formed. Despite the relative reduction in the number of requests in the following years, it should be noted that a certain average annual level was maintained in 2010-2020 research. At the same time, the dynamic search trends of the two categories are characterized by significant coincidence. It leads to the preliminary conclusion that studies of central bank independence are the primary category, while the transparency of the central bank is a derivative concept formed as a result of the development of the idea of ensuring the independence of the central bank.

The next step is to conduct a deeper analysis of the relationships between these categories that have emerged in preparing research in the world. We first analyze the scientific articles that were devoted to the study of central bank independence. The sample is made up of more than 700 articles indexed by the Scopus database, in which the words "central bank independence" are contained in the title, abstract or keywords of the paper. The tool of the analysis is the VOSviewer software, the application of which allows to determine the coincidence of keywords that occur simultaneously when writing articles related to the research of different aspects of central bank transparency. The results of the study are shown in Fig. 2. 


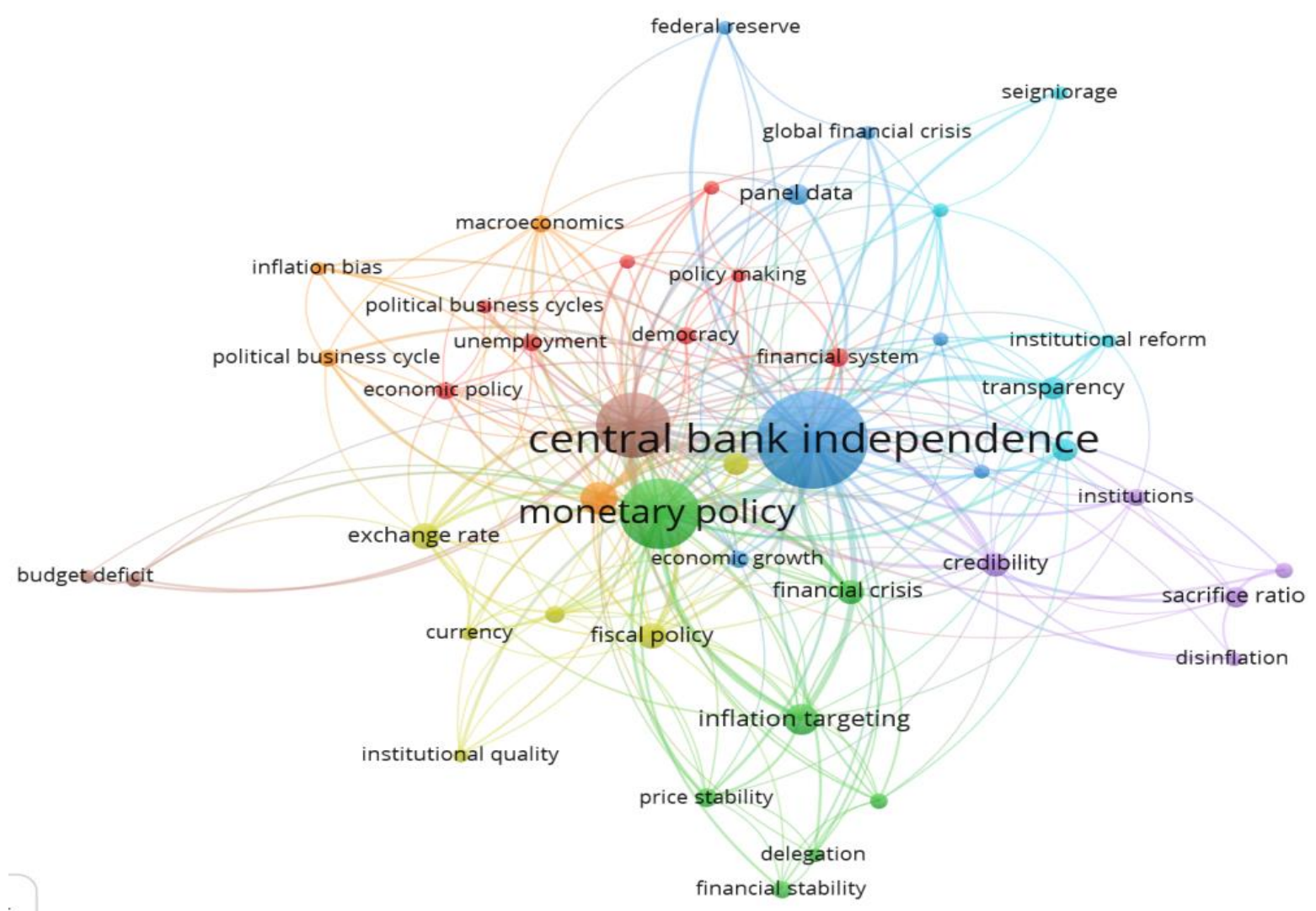

Figure 2. The results of the analysis of the keywords co-occurrence in Scopus papers related with "central bank independence" investigation using VOS viewer tools

Source: Own calculations by VOSviewer tool

The research tools enable us to distinguish different categories, the closeness of which occurs due to the frequency of coincidence of each of the two concepts in the list of keywords in a particular study. Besides, the frequency of occurrence and the combination of individual keywords allows you to identify clusters that include concepts that are most often jointly studied by scientists. The size of the circle for each concept illustrates the frequency of its occurrence in the total sample. Thus, most often the work devoted to the study of central bank independence also concerns the investigation of monetary policy and inflation. At the same time, the analysis of the composition of clusters formed by groups of keywords is a subject of considerable scientific interest. At this stage of the study, eight clusters were formed, each of them includes from 8 to 3 words (Table 1). The category "central bank independence" is included in cluster 3, which contains 7 keywords. It should be noted that the content of the concepts included in this cluster illustrate the goals that can be achieved directly or indirectly as a result of increasing central bank independence (governance, economic growth) or the conditions enhancing the role of central bank independence einsuring (globalization, global financial crisis).

Table 1. The results of analysis of the cluster items of keywords co-occurrence in Scopus papers related with "central bank independence" investigation

\begin{tabular}{|c|c|c|c|}
\hline Cluster 1 & Cluster 2 & Cluster 3 & Cluster 4 \\
\hline $\begin{array}{c}\text { Democracy } \\
\text { Economic policy } \\
\text { Empirical analysis } \\
\text { Financial system } \\
\text { Monetary institutions } \\
\text { Policy making } \\
\text { Political business cycle } \\
\text { Unemployment } \\
\end{array}$ & $\begin{array}{c}\text { Delegation } \\
\text { Financial crisis } \\
\text { Financial stability } \\
\text { Inflation targeting } \\
\text { Monetary policy } \\
\text { Price stability } \\
\text { Unconventional monetary } \\
\text { policy }\end{array}$ & $\begin{array}{c}\text { Central bank independence } \\
\text { Economic growth } \\
\text { Federal reserve } \\
\text { Global financial crisis } \\
\text { Globalization } \\
\text { Governance } \\
\text { Panel data }\end{array}$ & $\begin{array}{c}\text { Banking } \\
\text { Currency } \\
\text { Developing countries } \\
\text { Exchange rate } \\
\text { Fiscal policy } \\
\text { Institutional quality }\end{array}$ \\
\hline Cluster 5 & Cluster 6 & Cluster 7 & Cluster 8 \\
\hline $\begin{array}{l}\text { Credibility } \\
\text { Disinflation } \\
\text { Institutions } \\
\text { Openness } \\
\text { Sacrifice ratio }\end{array}$ & $\begin{array}{c}\text { Accountability } \\
\text { Institutional reform } \\
\text { Seigniorage } \\
\text { Transitional economy } \\
\text { Transparency }\end{array}$ & $\begin{array}{c}\text { Inflation bias } \\
\text { Macroeconomics } \\
\text { Political business cycle } \\
\text { Political economy }\end{array}$ & $\begin{array}{c}\text { Budget deficit } \\
\text { Inflation } \\
\text { National economy }\end{array}$ \\
\hline
\end{tabular}

Source: Own calculations by VOSviewer tool 
On the other hand, the category of "central bank transparency" was included in cluster 6, along with the concept of accountability, as well as categories that indicate the importance of ensuring the transparency of the central bank in the context of transformations (transitional economy, institutional reform). At the same time, such a division does not suggest that central bank transparency is a necessary aspect that must be explored when studying central bank independence.

On the other hand, there is a fairly close relationship between cluster 3 and cluster 2 . Given the fact that cluster 2 includes categories which the central bank should take into account (price stability, inflation targeting, financial stability etc.) or confront (financial crisis), it is quite natural and shows that the independence of the central bank is not a target category, but a basic one, which creates conditions for increasing its efficiency in achieving the final goals of central bank functioning.

This stage of the study did not allow us to definitively substantiate the substantive relationship between the categories of independence and transparency of central banks. That is why we will conduct a similar study of the composition of keywords in articles focused on the study of transparency of central banks. The sample of scientific articles on this topic included in the Scopus database is about 150 publications. The results of the analysis of the composition of keywords using the VOSviewer toolkit are presented by Fig. 3.

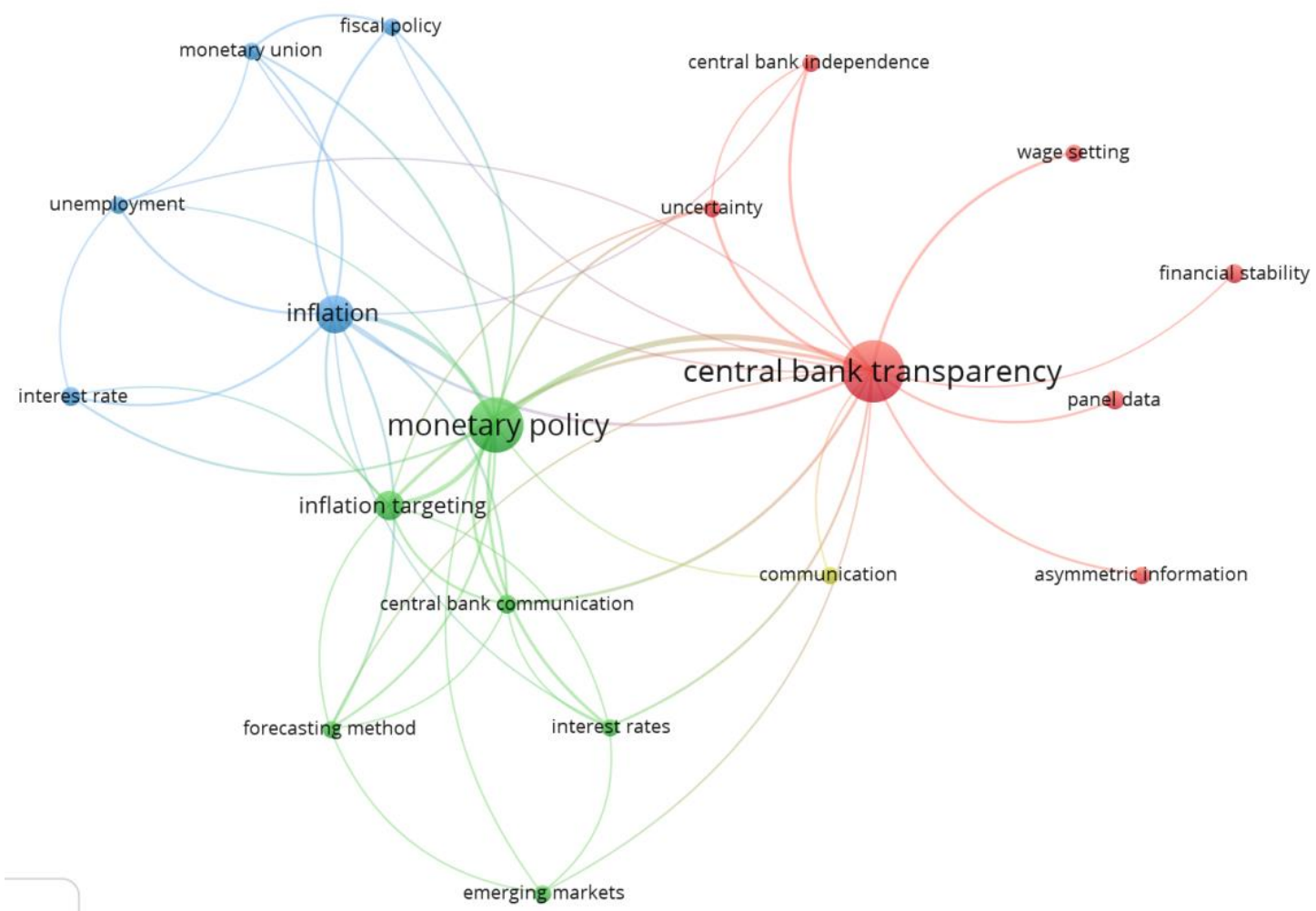

Figure 3. The results of the analysis of the keywords co-occurrence in Scopus papers related with "central bank transparency" investigation using VOSviewer tools

Source: Own calculations by VOSviewer tool

The results obtained at this stage show that the most common in research next to the category of "central bank transparency" are monetary policy and inflation, which are similar to previous results and are quite natural, given the basic conceptual framework of the central bank. At the same time, attention should be paid to the cluster structure of keywords identified in central bank transparency studies (Table 2).

Unlike the previous stage, within this block, the transparency and independence of the central bank belong to the same cluster. Besides, this cluster includes the concepts of financial stability, information asymmetry and uncertainty, which indicates the maximum effectiveness of the interaction of independence and transparency of the central bank in combating financial and information risks. Cluster 2, which includes market indicators of the banking system and methods used in monetary policy, is close to this cluster. 
Table 2. The results of analysis of the cluster items of keywords co-occurrence in Scopus papers related with "central bank transparency" investigation

\begin{tabular}{|c|c|c|c|}
\hline Cluster 1 & Cluster 2 & Cluster 3 & Cluster 4 \\
\hline Asymmetric information & Central bank communications & Fiscal policy & \\
Central bank independence & Emerging markets & Inflation & Communication \\
Central bank transparency & Forecasting method & Interest rate & \\
Financial stability & Inflation targeting & Monetary union & \\
Panel data & Interest rates & Unemployment & \\
Uncertainty & Monetary policy & & \\
Wage setting &
\end{tabular}

Source: Own calculations by VOSviewer tool

It should be noted that in the study of central bank transparency, the categories of independence and transparency of the central bank fall into one cluster, while in a similar analysis, the categories of "central bank independence" belong to different clusters. This allows us to conclude that the independence of the central bank is the primary category, which, in turn, creates the basis for research and development of transparency of the central bank.

\section{Conclusions, Discussion and Recommendations}

The study showed that there are close substantive and practical links between the categories of "central bank independence" and "central bank transparency". Existing empirical studies have shown that the independence and transparency of the central bank can serve as tools to increase the effectiveness of its main goals, such as price or financial stability, or become complementary components in improving the quality of the central bank's core tasks. A preliminary analysis of trends in the study of central bank independence and central bank transparency showed a declining trend in search queries from 2004 to the present, with a significant predominance of central bank independence over transparency throughout the study period. The results of bibliometric analysis of the coincidence of keywords in scientific articles devoted to the study of independence and transparency of the central bank, showed that the investigations of central bank independence concern the study of aspects of its transparency in a limited number of cases. Along with this, the central bank transparency is often studied simultaneously with the analysis of their independence. It enables to determine that the independence of the central bank is the primary category that creates the conditions for the study of its transparency. Obtained results provide a scientific basis for studying the strength and direction of the relationship between the levels of transparency and independence of the central bank, measured as quantitative indicators.

\section{References}

1. Balls E., Howat, J. and Stansbury, A. (2018). Central Bank Independence Revisited: After the financial crisis, what should a model central bank look like? M-RCBG Associate Working Paper Series, 87, 137. Available at: https://www.hks.harvard.edu/sites/default/files/centers/mrcbg/files/67_central.bank.v.2.pdf.

2. Bernanke, B. (2010). Central bank independence, transparency, and accountability. BIS Review, 72, 8. Available at: https://www.federalreserve.gov/newsevents/speech/bernanke20100525a.htm.

3. Crowe, C. and Meade, E. (2007). The Evolution of Central Bank Governance around the World. Journal of Economic Perspectives, 21(4), 69-90. DOI: 10.1257/jep.21.4.69.

4. Dincer, N. and Eichengreen B. (2014). Central Bank Transparency and Independence: Updates and New Measures. International Journal of Central Banking, 10(1), 189-253. https://www.ijcb.org/journal/ijcb14q1a6.htm.

5. Dumiter, F. C. (2014). Central Bank Independence, Transparency and Accountability Indexes: a Survey. Timisoara Journal of Economics and Business, 51(1), 35-54. DOI: 10.2478/tjeb-2014-0002.

6. Eijffinger, S. C. W. and Geraats P. (2006). How transparent are central banks? European Journal of Political Economy, 22(1), 1-21. https://doi.org/10.1016/j.ejpoleco.2005.09.013.

7. Fouad, J., Fayed M. and Emam H. (2019). A New Insight into the Measurement of Central Bank Independence. Journal of Central Banking Theory and Practice, 1, 67-96. DOI: 10.2478/jcbtp-2019-0004.

8. Garriga A. C. (2016). Central Bank Independence in the World: A New Dataset. International Interactions, 42 (5), 849-868. DOI: 10.1080/03050629.2016.1188813.

9. Ivanović, V. (2014). Financial Independence of Central Bank through the Balance Sheet Prism. Journal of Central Banking Theory and Practice, 2, 37-59. DOI: 10.2478/jcbtp-2014-0010.

10.Lustenberger, T. and Rossi, E. (2017). Does Central Bank Transparency and Communication Affect Financial and Macroeconomic Forecasts? SNB Working Papers, 12, 60. Available at: https://www.snb.ch/n/mmr/reference/working_paper_2017_12/source/working_paper_2017_12.n.pdf. 
11.Mathew, J. T. (2006). Measuring Central Bank Independence in Twenty - Five countries: A New Index of Institutional https://www.researchgate.net/publication/237218550_Measuring_Central_Bank_Independence_in_Twent y_Five_countries_A_New_Index_of_Institutional_Quality.

12.Oikonomou, G., Spyromitros, E. (2017). Trends in Central Bank Transparency. Theoretical Economics Letters, 7, 2089-2103. DOI: 10.4236/tel.2017.77142.

13.Pisha, A. (2011). Eurozone indices: a new model for measuring central bank independence. Bank of Greece Special Conference Paper. Available at: https://www.bankofgreece.gr/Publications/SCP201105.pdf.

14.Próchniak, M. and Szyszko, M. (2019). The similarity of European central banks in terms of transparency and effectiveness. Equilibrium. Quarterly Journal of Economics and Economic Policy, 14(3), 385-404. doi:0.24136/eq.2019.018.

15.Rizvanoghlu, I., Nagac, A. (2018). Central Bank independence and economic performance in Caucasus and Central Asian Countries. Journal of Eastern European and Central Asian Research (JEECAR), 5(2), 14. https://doi.org/10.15549/jeecar.v5i2.234.

16.Romelli, D. (2018). The Political Economy of Reforms in Central Bank Design: Evidence from a New Dataset. BAFFI CAREFIN Centre Research Paper, 87, 49. Available at: https://ideas.repec.org/p/tcd/tcduee/tep0918.html.

17.Schwödiauer, G., Komarov V., Akimova I. (2006). Central Bank Independence, Accountability and Transparency: The Case of Ukraine. FEMM Working Paper Series, 30, 43. Available at: https://www.econbiz.de/Record/central-bank-independence-accountability-and-transparency-the-case-ofukraine-schw\%C3\%B6diauer-gerhard/10003407298.

18.Smaghi, L. B. (2007). Central bank independence: from theory to practice. Available at: https://www.ecb.europa.eu/press/key/date/2007/html/sp070419.en.html.

19.Šmídková, K. (2013). Central Bank's Independence, Transparency and Accountability, Faculty of Social Sciences, Prague, November 11, 2013. Available at: http://ies.fsv.cuni.cz/default/file/download/id/29342.

20.Turkalj K. G., Ljubaj I. (2017). CNB Transparency and Monetary Policy. Croatian National Bank Surveys. S-25, 31. Available at: https://ideas.repec.org/p/hnb/survey/25.html.

21.van der Cruijsen C. A. B., Eijffinger S. C. W., and Hoogduin, L. H. (2010). Optimal Central Bank transparency. Journal of International Money and Finance, 29(8), 1482-1507. Available at: https://pure.uvt.nl/ws/portalfiles/portal/1250568/OCBT_JIMF.pdf. 